\title{
Countering Modern Terrorism: Military and other Options
}

\author{
Raphael Ejime \\ Middlesex University, United Kingdom
}

Doi: 10.19044/esj.2017.v13n32p1 URL:http://dx.doi.org/10.19044/esj.2017.v13n32p1

\begin{abstract}
Terrorism has been part of human development dating back to the era of the struggles for independence and liberation but still defy attempts at an accepted definition. Hence, it has become increasingly necessary for governments to tackle this menace by whichever counter-terrorism measures possible. However, one pivotal means is the use of military force introduced by the then President of the United States, George W. Bush through his "War on Terror" speech on September 20, 2001. This paper tries to assess the pros and cons of this measure and other counterterrorism strategies.
\end{abstract}

Keywords: Terrorism, military actions

\section{Introduction}

The use or threat of violence against unarmed civilians has been the gloomy part of human existence. Since the epoch of documented history, influential individuals and groups have been kidnapped and assassinated, and factions have demonstrated as well as perpetrated acts of non-conformity to the law through acts of violence, all in the name of pursuing a higher cause (Martin, 2013). Globalisation through the dawn of the internet and satellite communication has brought this phenomenon to the homes of people. Terrorist groups have put this technology to their advantage to convey their message to a wider range of audience; thus engendering empathy and fear (Martin, 2013).

Modern terrorism or "New Terrorism" as Martin (2013) puts it saw the bombing of the Twin Towers in New York on September 11, 2001, ushering in the threat and use of weapons of mass destruction (WMDs), arbitrary targeting and wide-reaching high casualty rates (Quillen, 2002). This is unlike traditional terrorism which involved classical structural formations with anticipated and balanced attacks, not identified on a mass casualty scale and extensive attacks (Laqueur, 2000). The former also provides a leeway for easy access to new technologies and the internet, benefits of globalisation for which 
terrorist groups aim to reach individuals with their atrocities within the convenience of their homes. Since the 9/11 attacks, terrorism has come to be seen to create fear and reach a wide target and produce extended durations of relevance (Laqueur, 2000).

Since the inception of new terrorism as Quillen (2002) observes, there has been an increase in casualty rate characterised by extensive, largely unstructured terrorist group formation and the use of unconventional methods. New terrorism has also led to the intensification of an unconventional method of counter-terrorism: military action exacerbated by the former President of the United States, George W. Bush's "War on Terror" speech on September 20, 2001 (Martin, 2013). The actions of 9/11 required an unconventional means to overcome the newly developed phenomenon, hence the use of military strategy to bring an end to terrorism as enunciated by George Bush (The Guardian, 2001).

That notwithstanding, there are other counter-terrorism strategies such as intelligence sharing, emergency legislation, and appeasement among others, which have been sacrificed and crushed under the tanks of military action (Benjamin, 2008; Hough, 2013). This work tries to assess the pros and cons of the military strategy against other counterterrorism measures in the fight against the new age of terrorism.

\section{Re-defining Terrorism}

Terrorism has defied any generally accepted definition with many definitions from analogous and conflicting hypothetical perspectives as well as from the standpoint of individuals, groups and organisations (Cooper, 2001; Simon, 1994). Terrorism is not novel; it has remained part and parcel of human development as far back as the struggle for emancipation and liberation (Martin, 2013). However, the difficulty in attaining an accepted definition of terrorism lies on the premise that terrorism occurs for several reasons: such as nationalistic, religious, political and ideological, among others (Laqueur, 2000; Martin, 2013; Baker, 2003; Townshend, 2011).

According to the US State Department of Terrorism (1983), terrorism is the "premeditated, politically motivated violence perpetrated against noncombatant targets by sub-national groups or clandestine agents usually intended to influence an audience" (USA 1983 in Hough 2013). Contentions arising from the above definition are on the basis that most violence perpetrated against non-combatants by clandestine agents are state organised and funded such as the assassination of innocent civilians in a bid to suppress terrorism (Martin, 2013).

Ganor (2005: 17) further describes terrorism as "a form of violent struggle in which violence is deliberately used against civilians to achieve political goals." His definition also accentuates premeditated violence in the 
form of 'deliberately used violence' to achieve political goals which may be nationalistic, ideological, socio-economic or religious etc. But Rapoport (1977) enunciated terrorism as "the use of violence to provoke consciousness, to evoke certain feelings of sympathy and revulsion." His definition brings to mind the saying that 'one man's terrorist is another man's freedom fighter' (Cooper, 2001). This definition posits that terrorists occasionally play on the empathic side of their targets when conveying their message. For instance, former South African President Nelson Mandela, an international antiapartheid icon, who died on December 5, 2013, was once labelled a terrorist by the US intelligence agencies (Windrem, 2013). As such, any complete definition of terrorism should encompass planned violence, political objectives, propagation of fear and directed against non-combatant targets; differentiating it from guerrilla warfare perpetrated against armed targets or any other form of violence (Nabulsi, 1999).

Terrorism as a tactic has been employed by very different groups and sometimes governments to achieve a certain purpose. Totalitarian and dictatorial governments were known to have used terror to maintain their power (Martin, 2013). It is instructive that definitions of terrorism from different perspectives have based the phenomenon on the idea that the state is the only legal body or agency having the legitimate monopoly of force - the right to use force or violence in any situation. Therefore, conscribing every use of force by non-state or sub-state actors as unlawful and unjustifiable; beseeching the question of the justifiable and legal status of all violence employed by the state (Martin, 2013). The question is then whether all violence employed by states are justifiable or legal) as totalitarian and dictatorial governments also use terror to maintain their power (Martin, 2013)?

As noted earlier, terrorism represents agelong tactics employed for several reasons (Barker, 2003), for social, economic, political and religious reasons and ideologies (Rapoport, 1984). Moreover, various counter-terrorist strategies have been used by states to curb this problem. These include the denial of entry to designated terrorists into certain countries; defending likely or possible terrorist targets. Also ending state sponsorship of and flow of resources to terrorists, as well as eliminating places deemed as lucrative, safe havens for terrorists such as failing states or conflicting emerging states (US Department of State, 2009). However, the new terrorism which came about in the wake of the terrorist attack of 9/11 has resulted in large-scale destructions of lives and property perpetrated under the guise of religion with mass casualty which has defied most of these counter-terrorist strategies (Quillen, 2002). That notwithstanding, the current Global War on Terror (GWOT), popularised by President George W. Bush in 2001 after the 9/11 attacks has remained the most all-encircling counterterrorist crusade on the record since the end of the Cold War (Jackson 2005), to curb this phenomenon. Incidentally, the figures 
of global terrorist attacks have increased drastically following the new terrorism (Martin, 2010). For example, between 2001 and 2005, the global terrorist attack figures rose from 1,732 to 4,995 (Martin, 2010) and 6,659 in 2006 (Martin, 2013). Such increase raises the question of if military tactics are the best strategy or method to end terrorism or combination of other counterterrorism strategies.

\section{Military Offensive against Terrorism:}

"Nothing in the present Charter shall impair the inherent right of individual or collective self-defence if an armed attack occurs against a Member of the United Nations until the Security Council has taken measures necessary to maintain international peace and security..." Chapter VII, Article 51, UN Charter (UN, n.d). This Article 51 of the UN Charter provides a springboard for states such as the United States (US) to justify their military based self-defence response against armed attacks (Bennis, 2005). Traditionally, the military comprises: "the Airforce, Army, Marine Corps, Coastguard and Navy" (Powers, 2016). Therefore, the use of military force in counter-terrorism involves the enlistment of these uniform men and women into a war with terrorists, encompassing the bombing of areas deemed to be harbouring terrorists and the detainment (sometimes unlawfully) of suspected terrorists (Colucci, 2013; US DoS, 2006).

In line with Global Policy Forum (n.d) and corroborated by Hough (2013) and Martin (2013), military action can be classified into two: Suppression or open campaigns (war) and covert operations. Suppression or open campaigns involve military strikes targeted against areas affiliated with terrorists to annihilate terrorists and damage terrorist infrastructures. Furthermore, it entails the use of "military or paramilitary assets to punish, destabilise, or destroy terrorist and their supporters" (Martin, 2013: 435). Military assets are formally recognised as enlisted members of the armed forces while paramilitary assets are government organised irregular individuals or units trained in the art of warfare (Martin, 2013). Examples of suppression campaigns include the 2002-3 Israeli organised Operation Defensive Shield in April 2002 to incapacitate efforts by Hamas (Martin, 2013). In Gaza, the capture of Mohammed Taha, a founding leader of Hamas, in one of the operations saw the death of eight Palestinians (Mackinnon, 2003); Taha was released later for reasons unknown (Staff, 2004). The 2001-2 Afghanistan war is also a typical example of an all-out war waged against equipped non-state actors (Hough, 2013).

Military and paramilitary strikes could be in response to terrorist aggression (punitive strikes) or expectancy of terrorist aggression (preemptive strikes) (Hough, 2004; Martin, 2013). Punitive strikes are a response to terrorist incidents that have already happened, deemed successful when 
partisan and representative links between the attacks and the terrorist incident are established (Martin, 2013). Pre-emptive strikes, on the other hand, refer to attacks launched to destabilise terrorists before the terrorist incident happens. Connections between the attacks and perceived threats must surface. A case in point of pre-emptive strikes is the 2003 US invasion of Iraq with the notion that the country possessed weapons of mass destruction (WMD) and Al Qaeda supposedly backed by Saddam Hussein's government (Martin, 2013).

Covert operations involve secretive operations that include the destabilisation and sabotage of suspected terrorist infrastructures as well as kidnapping and assassinations of individual terrorists, terrorist groups and support means (Martin, 2013). Covert assets also wage low key and clandestine 'shadow wars' which may involve assassination for which government 'plausible deniability' is guaranteed (Hough, 2004; Martin, 2013). Special Air Service (SAS) of Britain and the American Delta Force are illustrations of covert operation assets (Martin, 2013). For example, in March 2004, the Israeli war targeted against Hamas led to the assassination of Sheikh Ahmed Yassin, Hamas initiator and principal leader by Israeli aircraft fired missiles. The assassination was deemed necessary following Hamas taking responsibility for two suicide bombing incidents that claimed the lives of 10 Israelis that occurred about eight days before the assassination (Martin, 2013). Following the attacks of 9/11, the US reviewed her defence set up with some units becoming less special and having a specified security force (Hough, 2013). US drones strikes were also used kill members of Taliban, Al Qaeda and its affiliates in Pakistan between 2004 and middle of 2011. For the sake of this work, both suppression campaigns and covert operations are military offensive/action.

Military offensive has been deemed the most appropriate counterterrorist strategy following the September 20, 2001, former President Bush's "War on Terror" speech to combat new terrorism (Posen, 2015). However, the strategy has engendered a plethora of debate on its usefulness (Aliabbas, 2016; Wilkinson, 1996). For the advantages, the CIA (2003) identifies the military offensive as the most readily and primarily available strategy to minimise the damage caused by terrorists; striking at the core of terrorist infrastructures, camps, bases and countries supporting terror attacks. It is believed that this helps to deter corrupt foreign governments from supporting or harbouring terrorist organisations (US DoS, 2006). Furthermore, Ersen \& Ozen (2010) argue that military action discourages terrorist backing and inflicts destruction on terrorists and their sponsors.

According to them, the use of military action meets the demands of public and media for tough action against perpetrators of terrorism (Ersen \& Ozen, 2010). 
Also, Moltke (2012) suggests that military action is best suited to accomplish the objective of eliminating much of the terrorism dilemma as possible having the 'gloves are off' approach to terrorism. According to him, this symbolises the ability of the direct military action to render terrorists "off balance," disrupting and destabilising terrorists. In his opinion, military action based on the idea of "taking the fight to the enemy before he (the enemy) brings the fight home' is a form of defensive approach to dissuade or deter terrorists.

While not diminishing the positive sides of military tactics, there are also drawbacks to this over-eclipsing counterterrorism strategy (Hough, 2013; Smith, 2012; Colucci, 2013). Direct military engagements, most notably suppression campaigns have been observed to be more incapacitating than beneficial. According to Hough (2013: 85), "these limited military engagements have tended to be largely unsuccessful and possibly, even counter-productive," with the attendant huge collateral damage or civilian casualties. Such is the case in which US airstrikes allegedly killed at least 73 civilians in Northern Syria city of Manjib (Graham and Ackerman, 2016). There is also the issue of US military offensive mistakes perpetrated against Iraq and Afghanistan (Smith, 2012). Similarly, Nigerian security forces, in their bid to suppress the Boko Haram insurgents, have also been accused of extrajudicial killings (Amnesty International Report 2013), while hundreds of thousands of Iraqis have blamed the US troops for the loss of their beloved family members (Hough, 2013).

In addition, the use of military force entails large military budget which involves the creation of more weapons and the reduction of resources to other sectors of the economy (Barker, 2003). For example, the US military spending experienced a sharp increase following the terrorist attacks of 9/11, rising from below $\$ 400$ billion in 2001 to about $\$ 619$ billion before decreasing to $\$ 671$ billion in 2013 (Council on Foreign Relations, 2014). Furthermore, Barker (2003:136) affirms that the increased military budget, "the new knowledge and new technology may strengthen counter-terrorism, but they will eventually almost certainly add to the weapons and techniques available to terrorists". Barker (2013) claims that the increased volume of technology and weapons for states lead to increased access to technology and weapons to terrorists.

Additionally, various technologies and weapons are made available to terrorist, such as purchased, rented, or stolen private aircraft to the use of the internet to publish propaganda videos to encourage terrorists to undertake terrorist activities (InfoSec Institute, 2016). In 2002, a pilfered minuscule aircraft was crashed into a monetary company in inner-city Tampa, Florida by a 15-year-old student pilot. The student who was the only recorded fatality left behind a note articulating his backing and compassion for al-Qaeda aims and the 9/11 attacks (Homeland and FBI, 2008). Also, in 2005, a terrorist activity 
tracking company disclosed that a recognised jihadist website put forward an all-encompassing apprentice and learner's guide to hacking websites and breaking network security. The guide detailed computer security penetrating techniques and the targeting of specific computers as well as data on wellknown programs ale to break several internet firewalls (Homeland and FBI, 2008). Others include surface-to-air missile attacks such as the November 2002 unsuccessful shoulder-launched Man-Portable Air Defence System (MANPADS) strike against an Israeli charter plane leaving Mombasa, Kenya amongst others (Security service MI5, n.d).

To a large extent, the use of direct military action against terrorists only provides a loophole for the justification of terrorist attacks; unearthing new ways to strike at the heart of the different terrorised nations (Smith, 2011). In Nigeria, for example, the announcement of a major offensive against the Boko Haram sect in May 2013 saw the killing and arrest of many of its members (Ahokegh, 2012; Walker, 2012). However, months following the crackdown on Boko Haram members saw a rise in attacks on different targets in Maiduguri, NorthEast of Nigeria by the same sect (Allison, 2013). The whole point of terrorist attacks is to cause horrendous damage to aggravate massive retaliation (Smith, 2012). The correct response must, therefore, be dignified, deliberate, and appropriate such as former President Bush's "War on Terror" speech on September 20, 2001, which as a vivid illustration of the precise response to a successful and an effective terror attack (The Guardian, 2001). Smith (2012), while criticising the military counterterrorism strategy and arguing against the measure supports the link between the military counterterrorism and rise of terrorism. He argues that "When we attack terrorism with our military establishment, as we have done in Iraq and Afghanistan after 2003, terrorism morphs into insurgency" (Smith, 2012).

On another level, Kuipers (2004) argues that the use of military force in tackling terrorism erodes the confidence and trust of the people in the government of the day, which is the main aim of a terrorist group; to cause serious damage that the only retaliation is military action. He also stresses that the most appropriate method against terrorism involves the withholding of direct military confrontation; refuting the terrorist claims through transparency; demonstrating fairness and ingenuousness to criticism and working towards upholding socio-economic justice. This position brings to mind the idea espoused by Martin (2004), that it is necessary to appreciate the intensity of dissatisfaction of terrorists; the hub of their objectives and enthusiasm, and to understand their choice of campaign and targets, rather than dismissing them as illogical bloodthirsty fanatics. Accordingly, a better understanding of the terrorist organisations and terrorism must happen if the amelioration and end of the problem of terrorism is the goal. 
Allison (2013) agrees with the British Institute for Security Studies' senior researcher David Zounmenou (2014) that military action should not be a method of last resort against terrorism (Zounmenou and Zane, 2014). They argue that the use of military action in counterterrorism only proves the willpower and determination of a country in tackling terrorism (Allison 2013). Stern \& Wiener (2006) maintain that direct military action is a prerequisite for an anticipatory strategy in an attempt to incapacitate the threat before it occurs. However, Zounmenou and Zane (2014), as well as Allison (2013), noted that the application of this plan must accompany risk assessments-intelligence checking, drawing lessons from Iraq and Afghanistan where military operations were undertaken to recover Weapons of Mass Destruction (WMDs) which never existed. In the Iraq war for instance, while the US was criticised for its 'jackboot' tactics, the relative success credited to the British forces in Basra was as a result of the use of human intelligence and information sharing. These enabled them to win over liberal elements of the extremist groups and ensured that the die-hards were isolated and dealt with (Smith, 2012). Also, an analysis conducted by RAND of 648 terrorist groups that operated between 1968 and 2006 revealed that police investigation (40\%) and forms of political settlement (43\%) amounted for the larger portion of the disbandment of most groups (RAND, n.d in Townshend 2011: 144). However, the portion crushed by direct military force (10\%) was minute (RAND (n.d) in Townshend 2011: 144).

\section{Various Counter-Terrorism Measures}

Nevertheless, it is worthy of note that no one method or technique can successfully deal with the problem of terrorism which has eaten deep into the crux of society (Hough, 2004). Given the multinational dimension and sophisticated nature of terrorism, strong determination and cooperation lie on the part of society, law enforcement agencies and governments to beat this scourge. Information sharing between the public and law enforcement agencies should be encouraged. The involvement of citizens educated on the evils and ills of terrorism if terrorism is crucial if terrorism is to be eradicated or diminished.

It is therefore critically important that the war against terrorism requires a blend of different techniques and strategies. The use of the military to suppress terrorism or insurgency could be a key option based on the prevailing circumstances. Military force could be used to destabilise known terrorist threats, but this should only be used as a means of last resort when all other peaceful methods have proven abortive (Hughes, 2011).

Flowing from this, Gwyn Prins, of the London School of Economics, commented that: "There is no ultimate military solution to any of these things (terrorism). What you are doing is applying a bandage to a wound ... It is only 
desirable to use troops on the street if you can't possibly avoid it. You do consensual policing, that is what we do in Britain." (Meikle, 2011).

Furthermore, as noted by (Cronin 2009 in Hough 2013: 87) non-state political violence can only be suppressed through the careful combination of a range of strategies in any particular situation. He also affirms that traditional military response or action can only be beneficial where the direct threat is closely knit to a state as was the case of Afghanistan in 2002, where an apparent target was unwavering. The use of military force to combat or suppress terrorism can be beneficial mostly when the terrorist organisation is state-sponsored, or the terrorist threat is easily identifiable without causing high casualty to the society (Jackson, 2005). Buttressing this point, Hoffman (2001) affirms that terrorism requires the advancement of a comprehensive nationwide hybrid approach based on greater deliberation, an increased understanding and firmer appreciation of the threat and not just military action.

\section{Appeasement, Negotiations and Amnesty}

In other words, a range of national and international counter-terrorism strategies exist which could blend with military action being the last resort (Kirby, 2003; Meikle, 2011). One of these measures of state responses to terrorism and other forms of non-state violence include appeasement (Hough, 2004) for which the use of 'disarmament, demobilisation and reintegration' has become ubiquitous reaction in countries batting non-state violent groups (Muggah \& O'Donnell, 2015). For instance, in African countries, such as Nigeria, there is the Amnesty Program which involves the official pardoning of perpetrators of acts of crimes and terrorism and their continued rehabilitation (with regular stipend) of the participants concerned by the state, rather than punishment. The federal government of Nigeria in 2009 granted amnesty to the militants of the oil-rich Niger Delta region for laying down their weapons (Wall Street Journal, 2012).

However, one difficulty with this strategy is that it is only applicable to known terrorism within particular confines such as a state. But if the regular stipends should cease it is highly likely that ex-combatants will go back to arms to address their grievances as noted by Ebiede and Langer (2017) citing the emergence of other militant groups such as Niger Delta Avengers (NDA) following the end of the amnesty program in 2015 in Nigeria.

However, an end to militancy achieved with the peaceful signing of a peace deal between the Colombian government and the Revolutionary Armed Forces of Colombia - People's Army (FARC) is one of great pivots to the international system (Associated Press, 2016; Brodzinsky, 2016). The Peace deal negotiations began in September 2012 in Havana, Cuba while the revised deal signed on 26 September 2016 in the Colombian city of Cartagena has seen a peaceful resolution of disputes (Brodzinsky, 2016). The Peace deal 
came as a result of a Colombian peace process between the Colombian government and the FARC to reach an end to the five-decade-long Colombian conflict (Associated Press, 2016; Brodzinsky, 2016).

In another sense, the inability of any government to employ military action could portray weakness, enticing other sects to take up arms (House of Commons Foreign Affairs Committee, 2009). In light of this, Hough (2004: 78-9) suggested that the use of strategies such as appeasement and amnesty "could encourage other disavowed groups that violence pays dividends". Individuals not previously involved in violence could claim to be part of it to receive the financial payout (Ebiede \& Langer, 2017). If such a pay-out seems to stop it could lead to resurgence when no other option is considered viable (Ebiede \& Langer, 2017). Here, one can cite an example of the recent resurrection of the newly structured militant group in Eastern Nigeria, the Niger Delta Avengers (NDA) which declared its presence in March 2016 (BBC, 2016). The group has through its activities of destruction of oil producing facilities in the Delta, adversely affected the Nigerian economy (Ebiede \& Langer, 2017; The Economist, 2016). These activities by NDA has caused the closure of several oil stations in Nigeria (Ebiede \& Langer, 2017). It has also led to a decrease in Nigeria's total oil production level in 2016 from 2.2 million to about 1.1 million barrels per day (Ebiede \& Langer, 2017) causing its title of Africa's largest oil producer to go to Angola (Holodny, 2016). Nigeria, has thus, been unable to tackle the menace through the use of military force as the group continues to undermine any direct military encounter (Ebiede \& Langer, 2017).

According to Ebiede and Langer (2017), the most appropriate strategy to curb the insurgency in Eastern Nigeria and increase its oil production as well as revenue is not the military strategy but the sustenance and plausible development of the amnesty program However, it is suggested that any amnesty should not accentuate financial imbursements to ex-combatant but deal with underlying subjects such as the reassessment of environmental pollution in the area and development issues where in Africa and Nigeria in particular, development issues and insurgencies are ubiquitous (Ebiede \& Langer, 2017).

Some countries such as Russia however pursue zero-tolerance attitude to appeasement (Hough, 2004). In light of this, President Putin (2004 in Hough, 2004) vehemently expressed his dissatisfaction with this strategy and his preference for a military offensive against terrorism arguing, that "Russia does not negotiate with terrorists, it destroys them". Following the double female suicide bombers' attack on Russian trains which led to the death of 38 people in Moscow in March 2010, the then Prime Minister, Putin again stated in a video conference: "I am confident that law enforcement bodies will spare no effort to track down and punish the criminals. Terrorists will be destroyed," 
(Harding \& Tran, 2010). Hence, the military strategy seems very palatable to some countries than most. Moreover, Ebiede and Langer (2017) argues that the success of any 'disarmament, demobilisation and reintegration' program, especially in Africa, depends largely on the ability to engage ex-combatants in a long-term program and reintegration into civilian and social life.

\section{Hardening Potential Targets}

The 'hardening target' strategy also referred to as containment (Hough, 2004) involves the securing and protection of vulnerable segments of society most likely to come under terror attack. Activities include securing transportation centres, public health services, observable deployment of security staff to chemical and defence industries, defence of religious centres, schools and restaurants (USDoS, 2006). It follows that governments of countries look for ways to secure their countries and citizens in the wake of recurring terrorist attacks by containing such threats through these measures (Hough, 2004). Unlike the military strategy which more often than not would result in a confrontation with terrorists who most likely would have perpetrated the acts before being caught or attacked, this strategy serves as a defensive mechanism making formerly appealing targets look less palatable to terrorists (US DoS, 2006).

With regards to hardening target measure, examples in Britain include the erection of boulders (Mann, 2017) to prevent vehicular attacks and 'talon' spiked nets (Farmer, 2017) designed to puncture tyres and halt terrorist vehicles including lorries weighing about 17 tonnes (Daerden, 2017) when an attack occurs. These measures come as a result of the increase in vehicular terrorist attacks across Europe, such as the London's Westminster Bridge attack on 22 March 2017 in which a car ploughed into pedestrians before crashing into the railings by the House of Parliament (Said-Moorhouse and Dewan, 2017). Again, this strategy is not fool-proof as noted by US DoS (2006), arguing that terrorists seek out specific symbolic targets to "produce mass casualties, economic damage, or both". Moreover, more than just deterring or and interrupting terrorist attacks, this strategy helps to lessen the effects of supposedly terrorist attacks that tend to slip through the cracks of the improved security measures. Thus, efforts should be made to secure pivotal infrastructures and resources such as the information and telecommunication, energy, water, historical sites, attractions and monuments as well as commercial facilities among others, whose damage can be debilitating to any country (US DoS, 2006).

Also, hardening potential targets and securing symbolic areas does tend to come at a price for which most individuals are sometimes more than happy to bear (US DoS, 2006). For instance, in the US, following the events of $9 / 11$ in which terrorists took advantage of the lax aviation security 
measures, people are now more keen to bear the extra wait time at the airports. These stringent measures put in place to forestall a likelihood of the events of 9/11 are necessary as long as their security is guaranteed (Hough, 2013). Hough (2013) points out that striking a balance between freedom of citizens and the task required to achieve security in the face of new terrorism remains a pressing issue.

That notwithstanding, as warned by Moltke (2012), the 'hardening target' strategy should never be the sole foundation of counterterrorism but for deterrence purposes only. It, therefore, cannot effectively quell terrorist attacks, though it can serve as deterrence to terrorist plotters (Moltke, 2012, US DoS, 2006).

\section{Legal measures against terrorism}

The 'War on Terror' is believed to have perpetuated a regime of fear and subjugation which has rather than alleviating terrorism has fashioned enemies and engendered violence putting to futility the actions of mitigating terrorism (GFP, n.d). The strategy has also been suggested to provide a leeway for governments to suppress minority groups and opposition with a blatant indifference to civil rights and international law. Governments are expected to deal with the problem of terrorism through international cooperation, respect for human rights and upholding the international law while identifying the source of terrorism and issues which give rise to state-sponsored violence (GPF, n.d).

Barker (2003) advocates the downplaying of this measure and the use of legislation. He cites countries such as Britain, Australia and Canada among others that have since 9/11 introduced various pieces of legislation to combat terrorism (US DoS, 2006). Countries have introduced 'emergency legislation which includes the removal of citizenship rights from suspects belonging to the country or the withholding of certain rights and privileges from noncitizens within their country (US DoS, 2006; Hough, 2013). Britain, for example, has presented five key pieces of terrorism legislation since the year 2000. Among these is the Prevention of Terrorism Act 2005 which grants control order powers to the government to restrict the movement of individuals suspected of terrorist activities for which there is less evidence for the prosecution or legal charging of such people (Hanman, 2009).

However, these pieces of legislation have been criticised on several grounds such as the infringement of individual rights and widespread stopand-search, among others (Hanman, 2009). Moreover, the House of Lords in a 2004 ruling condemned segments of the Anti-Terrorism Crime and Security Act 2001 (which allows the British government to detain 'ad infinitum' without trial, foreign citizens alleged of terrorism connections) as discordant with human rights because it was discriminatory based on nationality. These 
actions led to the readjustment and introduction of the Prevention of Terrorism Act 2005 to include control orders to the entire British public (Hanman, 2009).

In Australia, the country has been labelled 'authoritarian' following the introduction of about 60 pieces of terrorism-related legislation since 2002 (Barns, 2015). Just like Britain, Australia tries to detain individuals for more than 28 days without charge seen as belligerent and a deprivation of liberty or chance of bail (Barns. 2015). Moreover, there has also been the unlawful treatment of suspected terrorists and illegitimate detention of persons in prisons such as Guantanamo Bay in Cuba and Abu Ghraib in Iraq employed by the US (Hough, 2004). That notwithstanding, the significance of legislation as a technique in the fight against terrorism continues to rise, yet the question remains if citizens are to give up their rights to help end terrorism to avoid civilian blood-shed through military force.

Barker in his book, "The No-Nonsense Guide to Terrorism" still argues that terrorism should not be regarded as primarily a military issue but that terrorists are criminals committing crimes against humanity; thus depriving them of the toga of heroic warriors (Barker, 2003). Hanrahan et al. (2004) suggest the proscription of terrorist groups that lead to the forming of legitimate political wings. Here, their spokesperson/s or former member(s) advancing their cause in a non-violent manner should be another method used by the government seeking to redress grievances appropriately, just like in Colombia, where the peace deal between the Colombian government and FARC. Colombia FARC has transformed into a political party (Al Jazeera, 2017).

\section{Conclusion}

Terrorism has assumed a complex and sophisticated dimension and requires an equally sophisticated, multidimensional and integrated solution. The cooperation of all stakeholders, including the security agencies, governments and the larger population is crucial in routing out the scourge. While military action may succeed in some cases, it should not be a cure-all approach. The use of a combination of options mentioned above, including appeasement (used to a certain degree), persuasion, amnesty program, cultivation and constructive engagement of all segments of society is more likely to yield the most counterterrorism results.

Besides military action, there is an array of other counter-terrorism strategies and measures that could be employed to deal with the situation at different levels or point in time (Hough 2013). Going by the examples of U.S. "War on Terror," military action may look attractive as the primary source of destruction to any form of terrorist attack, protecting the society and circumventing any terrorist attack. Nonetheless, it is believed to cause more 
damage than repair such as the infringement on and curtailing of the rights of citizens.

Moreover, there is always a constant of civilian casualty or collateral damage, no matter how much attention or plan goes into the military strategy. As such, hundreds of thousands of Iraqis have blamed the US troops for the loss of their beloved family members (Hough 2013).

Every problem requires an understanding of the cause and terrorism is no exception. Therefore an important solution may involve the redress the root-causes of grievances and employment of peaceful methods of settlements such as appeasement, negotiation and dialogue among others. Even where these options are proving unsuccessful, military action should only be a means of last resort.

More importantly, counterterrorism efforts directed at winning the hearts and minds of the people where terrorists operate should be encouraged in favour of the military option against the terrorists themselves and not the other way around. Terrorists live amongst the population, and one man's terrorist may be another man's freedom fighter. The use of military action alone may even radicalise the liberal elements or win sympathy for a terrorist group (Smith, 2011).

Moreover, a measure of counterterrorism success has been attributed to effective law enforcement and intelligence sharing mechanisms (Benjamin, 2008). By and large, since there is no fool-proof strategy against terrorism, the context and modus operandi of a given terrorist group will determine whether a single or hybrid counter-terrorism approach will be best suited, depending on the individual circumstances. Also, in determining which strategy to deploy, a high consideration must be placed on the fundamental rights of citizens; protection of lives and property, and the national interest.

\section{References:}

1. Al Jazeera (2017) Colombia FARC transforms into a political party [Online] Al-Jazeera. Available at: <http://www.aljazeera.com/news/2017/09/colombia-farc-transformspolitical-party-170902005950448.html> [Accessed on 22 October 2017]

2. Allison, S. (2013). Boko Haram cannot be beaten by Guns Alone [online] Available at <http://www.theguardian.com/world/2013/dec/03/nigeria-bokoharam-analysis $>$ [Accessed 28 December 2013].

3. Ahokegh, A. F. (2012) Boko Haram: A 21st Century Challenge in Nigeria. European Scientific Journal. Vol 8, No.21 [Online] Available at: 〈http://eujournal.org/index.php/esj/article/view/334> [Accessed on: 22 June 2016] 
4. Associated Press (2016) Colombia's government Formally Ratifies Revised FARC Peace Deal [Online] The Guardian. Accessed on: <https://www.theguardian.com/world/2016/dec/01/colombiasgovernment-formally-ratifies-revised-farc-peace-deal $>$ [Accessed on 22 January 2017]

5. Barker, J. (2003). The No-Nonsense Guide to Terrorism. London: New Internationalist Publishers Ltd.

6. Barns, G. (2015) Welcome to Authoritarian Australia, Where more Anti-Terror laws won't keep us Safe [Online] The Guardian. Available at:

<https://www.theguardian.com/commentisfree/2015/oct/13/welcometo-authoritarian-australia-where-more-anti-terror-laws-wont-keep-us-

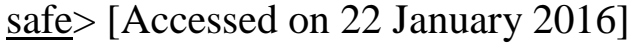

7. Benjamin, D. (2008) Strategic Counterterrorism. Foreign Policy at Brookings. Policy paper. Available at:

<https://www.brookings.edu/wpcontent/uploads/2016/06/10_terrorism_benjamin.pdf $>$ Accessed on 25/01/2016]

8. Bennis, P. (2005) Article 51: Self-Defense and its Limits in the UN Charter [Online] Transnational Institute. Available at: <https://www.tni.org/en/archives/act/729> [Accessed on 04 January 2014]

9. Bjorgo, T. (2005) (e.d.). Root Causes of Terrorism: Myths, Reality and Ways Forward. New York: Routledge.

10. Bowden, M. (2012) The Death of Osama Bin Laden: How the US finally got its Man [Online] The Guardian. Available at: <https://www.theguardian.com/world/2012/oct/12/death-osama-binladen-us> [Accessed on: 22 October 2017]

11. Brodzinsky, S. (2016) Colombia Signs Historic Peace deal with FARC. [Online] The Guardian. Accessed on: <https://www.theguardian.com/world/2016/nov/24/colombia-signshistoric-peace-deal-with-farc-rebels $>$ [Accessed on 22 January 2017]

12. CIA US (2003). National Strategy for Combating Terrorism. [Pdf] CIA. Available at: <https://www.cia.gov/news-information/cia-thewar-on-terrorism/Counter_Terrorism_Strategy.pdf $>\quad$ Accessed 23.12.2013.

13. Colucci, L. (2013) 10 Reasons the War on Terror Must Continue. [Online] Available at <https://www.usnews.com/opinion/blogs/worldreport/2013/06/18/10-reasons-the-global-war-on-terror-mustcontinue> [Accessed on 01/02/2015]

14. Cooper, H. H.A (2001) Terrorism: The Problem of Definition Revisited American Behavioural Scientist, Vol. 44, No. 6. in Martin, 
G. (2004) The New Era of Terrorism: Selected Readings. California, Thousand Oaks: Sage Publications.

15. Council on Foreign Relations (2014) Trends in US Military Spending [Online] Council on Foreign Relations. Available at: <https://www.cfr.org/report/trends-us-military-spending > [Accessed on 01/02/2015]

16. Cronin, A. (2009). How Terrorism ends, in Hough, P. (2013) Understanding Global Security $3^{\text {rd }}$ edn. New York: Routledge.

17. Daerden, L. (2017) 'Talon' spikes introduced in London to halt vehicle terror attacks [Online] Independent. Available at: <http://www.independent.co.uk/news/uk/home-news/talon-spikeslondon-stop-lorry-terror-attacks-vehicle-truck-met-police-scotlandyard-events-a7940246.html > [Accessed on: 22 October 2017]

18. Ebiede, T., M. \& Langer, A. (2017) How Amnesty Efforts in the Niger Delta Triggered New Violence. [Online] The Conversation. Accessed on: <http://theconversation.com/how-amnesty-efforts-in-the-nigerdelta-triggered-new-violence-74085> [Accessed on 22 January 2017]

19. Ersen, U \& Ozen, C (2010) (eds.) Use of Force in Countering terrorism. Netherlands: IOS Press BV.

20. Farmer, B. (2017) Lorry-stopping 'super stinger' spiked net unveiled to protect crowds against terror attacks [Online] The Telegraph. Available at: <http://www.telegraph.co.uk/news/2017/09/10/lorrystopping-super-stinger-spiked-net-unvelied-protect-crowds/>

[Accessed on 22 October 2017]

21. Ganor, B. (2005). The Counter-Terrorism Puzzle: A Guide for Decision Makers. New Brunswick, NJ: Transaction Publishers.

22. Global Policy Forum (n.d) War on Terrorism [Online] GPF Accessed at <https://www.globalpolicy.org/war-on-terrorism.html> [Accessed on 22 June 2017]

23. Graham, E and Ackerman, S. (2016) US Airstrikes allegedly kill at Least 73 Civilians in Northern Syria [Online] Available at <https://www.theguardian.com/world/2016/jul/20/us-airstrike-

allegedly-kills-56-civilians-in-northern-syria $>$ [Accessed on 01/02/2017]

24. Hanman, N. (2009) Explainer: Terrorism Legislation [Online] The Guardian.

<https://www.theguardian.com/commentisfree/libertycentral/2009/ja

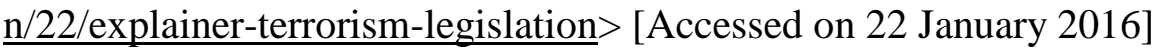

25. Hanrahan, B. et al. (2004) Transitions from Violence to Politics: Conditions for the Politicization of Violent Non-State Actors [Online] [pdf] Naval Postgraduate School. Monterey, California Available at: 
<file:///C:/Users/re222/Desktop/15Dec_Hanrahan_Woody.pdf> [Accessed on: 03/04/2016]

26. Harding, L. \& Tran, M. (2010) Moscow Metro Bombs kill Dozens. [Online] The Guardian. Available at: $<$ https://www.theguardian.com/world/2010/mar/29/moscow-metrobombs-explosions-terror> [Accessed on 22 June 2017]

27. Hoffman, B. (2001) Combating terrorism: In Search of a National Strategy. [Online] CT-175, xRAND. Accessed at: $<$ https://www.google.co.uk/es_sm=93\&espv=210\&q=Hoffman, + B.+ + (2001)+Combating+terrorism:+In+Search+of+a+National+Strategy.+ CT-175,+gRAND+March+27,+2001\&spell=1\#> [Accessed 14 December 2013]

28. Hough, P. (2004) Understanding Global Security $2^{\text {nd }}$ edn. New York: Routledge.

(2013) Understanding Global Security $3^{\text {rd }}$ edn. New York:

Routledge.

30. Homeland Security \& FBI (2008) Potential Terrorist Attack Methods [Online] [Pdf] National Security Archives: Office of Intelligence and Analysis. Available at: 〈http://nsarchive2.gwu.edu/nukevault/ebb388/docs/EBB015.pdf > [Accessed on 22 June 2017]

31. House of Commons Foreign Affairs Committee (2009) Global Security: Afghanistan and Pakistan. Eight Report of Session 2008-09. House of Commons Foreign Affairs Committee. London: The Stationery Office Ltd

32. Hughes, G. (2011) The Military's Role in Counterterrorism: Examples and Implication for Liberal Democracies. [Online] The Latent Papers. Accessed at $:<\mathrm{https} / / / \mathrm{ssi}$.armywarcollege.edu/pdffiles/PUB1066.pdf $>$ [Accessed on: 22 June 2015]

33. InfoSec Institute (2016) The Role of technology in Modern terrorism [Online] InfoSec Institute. Available at: $<$ http://resources.infosecinstitute.com/the-role-of-technology-inmodern-terrorism/\#gref> [Accessed on 22 July 2017]

34. Jackson, R. (2005). Writing the War on Terrorism: Language. Politics and Counter-Terrorism. Manchester: Manchester University Press.

35. Laqueur, W. (2000) The New Terrorism: Fanaticism and the Arms of Mass Destruction. Oxford: Oxford University Press

36. Kirby, A. (2003) War 'should be Last Resort'. [Online] BBC. Available at: <http://news.bbc.co.uk/1/hi/uk/2788433.stm> [Accessed on 22 June 2017] 
37. Kuipers, B. (2004). How to Defeat Terrorism. [Online] Available at: $<$ http://www.cs.utexas.edu/users/kuipers/opinions/defeatingterrorism.html> [Accessed 02 January 2014].

38. Kurtulus, E., N. (2011) The New Terrorism and its Critics. [Online] Taylor \& Francis Online. Studies in Conflict \& Terrorism. Vol 34, Issue 6, pp. 476-500. Available at <http://www.tandfonline.com/doi/abs/10.1080/1057610X.2011.57119 4? src=recsys\&journalCode=uter20 $>$ [Accessed 23/01/2017]

39. Mackinnon, M. (2003) Senior Hamas Leader held as Israel hits Gaza Camp [Online] The Globe and Mail. Available at: < https://beta.theglobeandmail.com/report-on-business/senior-hamasleader-held-as-israel-hits-gaza-camp/article22393487/> [Accessed on: 02 July 2016]

40. Mann, T. (2017) The latest Weapon that's Protecting the UK from Terrorism [Online] Metro. Available at: < http://metro.co.uk/2017/03/24/the-latest-weapon-thats-protecting-theuk-from-terrorism-6531349/> [Accessed on: 22 October 2017]

41. Martin, G. (2004) The New Era of Terrorism: Selected Readings. Thousand Oaks, CA: Sage Publications.

42. (2010). Understanding Terrorism: Challenges, Perspectives, and Issues. Thousand Oaks, CA: Sage Publications.

43. (2013). Understanding Terrorism: Challenges, Perspectives and Issues. $3^{\text {rd }}$ ed Thousand Oaks, CA: Sage Publications.

44. Meikle, J. (2011) London riots: army should be last resort, say Experts. [Online] The Guardian. Available at: <https://www.theguardian.com/uk/2011/aug/09/london-riots-armylast-resort> [Accessed on 22 June 2017]

45. Mingst, K. (1999) Essentials of International Relations, New York: W. W. Norton \& Company, Inc.

46. Moltke, H. V. (2012). Counterterrorism: Military and Economic Options: "No military plan survives its first contact with the enemy" [Online] Available at $\langle$ http://www.drtomoconnor.com/3400/3400lect08a.htm> [Accessed on 20 June 2015]

47. Muggah, R. \& O'Donnell, C., (2015). Next Generation Disarmament, Demobilization and Reintegration. Stability [Online] International Journal of Security and Development. 4(1), part. 30. Available at: $<$ http://doi.org/10.5334/sta.fs $>$ [Accessed on 22 June 2017]

48. Nabulsi, K (1999) Traditions of War. Oxford: Oxford University Press; Ticehurst, Rupert (1997). The Martens Clause and the Laws of Armed Conflict. International Review of the Red Cross, 317, 125-134. 
49. Obi, E. \& Ozor, C. (2009) The Process of International relations: Theories, Processes \& Institutions, Onitsha: Bookpoint Educational Ltd.

50. Oluokun, A. (2014) Nigeria, Boko Haram And Past Failed Negotiations. [Online] The News Available at: < http://thenewsnigeria.com.ng/2014/10/nigeria-boko-haram-and-pastfailed-negotiations/> [Accessed on 24 June 2017]

51. Powers, R. (2016) U.S. Military 10. [Online] The Balance. Available at: < https://www.thebalance.com/u-s-military-101-3331988> [Accessed 20 January 2017]

52. Putin, V. (2004) Terror in the Moscow Subway. MOSnews in Hough, P. (2004) Understanding Global Security $2^{\text {nd }}$ edn. New York: Routledge.

53. Quillen, C. (2002) A Historical Analysis of Mass Casualty Bombers from Martins, G. (2004) The New Era of Terrorism: Selected Readings. California, Thousand Oaks: Sage Publications.

54. RAND (2008) Counter-Terrorism: Tacking on Terrorists, Is military Force the Best Means to Defeat Terrorist Groups. [Online] RAND. Available at: <http://www.economist.com/node/11950796> [Accessed 07 January 2014]

55. Rapoport, D. C. (1977) The Government Is Up in the Air over Combating Terrorism. [pdf] National Journal, 9, 1853-1856. Available at: 〈http://www.sagepub.com/upm-data/51172_ch_1.pdf > [Accessed 02 January 2014] (1999). Terrorism: Encyclopaedia of Violence, Peace and Conflict. San Diego, CA: Academic Press

57. Richard, J. (2005). Writing the War on Terrorism: Language, Politics and Counter-Terrorism. Manchester, England: Manchester University Press.

58. Said-Moorhouse, L. and Dewan, A. (2017) London Attack: Assailant shot dead after four killed near Parliament [Online] CNN. Available at: $\quad$ http://edition.cnn.com/2017/03/22/europe/uk-parliamentfirearms-incident/index.html $>$ [Accessed 22 June 2017]

59. Security service MI5 (n.d) Terrorist Methods [Online] Security Services MI5 Available at <https://www.mi5.gov.uk/terroristmethods $>$ [Accessed on 22 October 2017]

60. Simon, Jeffrey D. (1994). The Terrorist Trap. Bloomington: Indiana University Press.

61. Smith, J., R. (2012) US. Military Admits Major Mistakes in Iraq and Afghanistan [Online] Available at $<$ https://www.theguardian.com/world/2016/jul/20/us-airstrike- 
allegedly-kills-56-civilians-in-northern-syria> [Accessed on $01 / 02 / 2015]$

62. Staff, H. (2004) Israel Releases Hamas Co-Founder Mohammed Taha [Online] Haaretz. Available at: <https://www.haaretz.com/israelreleases-hamas-co-founder-mohammed-taha-1.121655> [Accessed on: 02 July 2016]

63. Stern, J. and Wiener, J. (2006). Precaution Against Terrorism. Journal of Risk Research Vol. 9, No. 4, 393-447, June 2006. Routledge.

64. The Guardian (2001) Text of George Bush's Speech. [Online] The Guardian.

Accessed

on:

https://www.theguardian.com/world/2001/sep/21/september11.usa13

$>$ [Accessed on: 22 January 2015]

65. Townshend, C. (2011). Terrorism: A Very Short Introduction. New York: Oxford University Press.

66. US Department of State (2006) National Strategy for Combating Terrorism. [Online] US DOS Archives. Available at: <https://20012009.state.gov/s/ct/rls/wh/71803.htm> [Accessed on 13/07/2017]

67. USA (1983) United States Code, Title 22 Section 2656f (d), in Hough, P. (2013) Understanding Global Security $3^{\text {rd }}$ edn. New York: Routledge.

68. Walker, A. (2012) What is Boko Haram? United States Institute of Peace, June 2012, Special report 308 Special Report pp. 1-16

69. Windrem, R. (2013) US Government considered Nelson Mandela a Terrorist until 2008 [Online] NBC News. Available at: $<$ https://www.nbcnews.com/news/other/us-government-considerednelson-mandela-terrorist-until-2008-f2D11708787> [Accessed on 13/07/2017]

70. Zounmenou, D \& Zane, M. (2014) Nigeria's Fight against Boko Haram. How can France Help? [Online] ISS. Available at: $<$ https://issafrica.org/iss-today/nigerias-fight-against-boko-haramhow-can-france-help $>$ [Accessed 07 January 2015] 